\title{
Pectinolytic and Cellulolytic Activity of Soil Fungal Isolates From Similipal Bioreserve Forest
}

\author{
S. S Panda ${ }^{1, *}$, K. Sahoo ${ }^{1}$, R. Das ${ }^{2}$, N. K Dhal ${ }^{1}$ \\ ${ }^{1}$ Environment and Sustainability Department, Institute of Minerals and Materials Technology (CSIR), Bhubaneswar-751013, India \\ ${ }^{2}$ Department of Botany, Utkal University, Bhubaneswar-751013, India
}

\begin{abstract}
Twenty five fungal strains were isolated from soil of Similipal Bioreserve Forest and screened for pectinase and cellulase activity. Aspergillus sp. was found to be predominant in the sample. Out of which, Aspergillus niger and $A$. flavus showed high cellulolytic and pectinolytic activity having potency index of 4.5 for $\mathrm{I}_{\mathrm{Fcel}}$ and 4.1 for $\mathrm{I}_{\mathrm{Fpect}}$, respectively. Parameters like $\mathrm{pH}$ and temperature were optimized for the potent strains. The present study concludes that both of the strains can be further utilized for large scale industrial purpose.
\end{abstract}

Keywords Aspergillus sp., cellulase, pectinase, $\mathrm{pH}$, temperature

\section{Introduction}

In nature, microorganisms have been endowed with vast potentials. They produce an array of enzymes, which have been exploited commercially over the years. Pectinolytic and cellulolytic enzymes are known to produce by many organisms and are useful for invading host tissues. Moreover, these enzymes are essential in the decay of dead plant material by non-pathogenic microorganisms and thus assist in recycling carbon compounds in the biosphere[1].

Pectinases are important for plants as they help in cell wall extension and softening of some plant tissues during maturation and storage. They also aid in maintaining ecological balance by causing decomposition and recycling of waste plant materials. It catalyses the degradation of the pectins via depolymerization and de-esterification reactions [2]. Cellulase is a complex enzyme composed of cellobiohydrolases, endoglucanases and $\beta$-glucosidases which all act synergistically to convert complex carbohydrates present in lignocellulosic biomass into glucose efficiently[3]. These are inducible enzymes which are synthesized by microorganisms during their growth on cellulosic materials[4]. These are studied extensively due to their application in the hydrolysis of cellulose, the most abundant biopolymer and potential source of utilizable sugars, which serves as a raw material in the production of chemicals and fuel. Both the enzymes, pectinase and cellulase(s) are industrially important enzymes that are sold in large volumes for use in different industrial applications, for example in starch processing, animal feed production, grain alcohol fermentation,

* Corresponding author:

swati.sucharita8@gmail.com (S.S Panda)

Published online at http://journal.sapub.org/env

Copyright (C) 2012 Scientific \& Academic Publishing. All Rights Reserved malting and brewing, extraction of fruit and vegetable juices, pulp and paper industry and textile industry[5,9].

The present investigation was based on screening of pectinolytic and cellulolytic enzyme activities of the fungal strains isolated from Similpal Bioreserve Forest soil and optimization of culture conditions of the potent isolates.

\section{Materials and Methods}

\subsection{Study Area}

Similipal Bioreserve Forest is located between $21^{\circ} 35^{\prime}$ and $22^{\circ} 01^{\prime}$ 'north latitude and $86^{\circ} 13^{\prime}$ ' and $86^{\circ} 37^{\prime}$ ' east longitudes. It is situated in Mayurbhanj district of Odisha state. The significance of the Bioreserve Forest is its rich biodiversity as it was protected from anthropogenic activities. Soil sample was collected from three different areas of forest, Jenabil, Bhanjabasa, and Barakanda.

\subsection{Isolation and Identification of Fungi}

Soil samples were collected randomly under aseptic condition from the Simipal Bioreserve Forest, Odisha. The fungal isolation from soil samples has been carried out by serial dilution method on CDA (Czapek Dox Agar) medium and the plates were incubated at $28-30^{\circ} \mathrm{C}$ for 48 to 72 hours. The fungal isolates were then preserved at $3-4^{\circ} \mathrm{C}$ for further study. The fungal isolates were examined and identified based on morphological and microscopical characteristics by following the keys by Talbot and Deacon[10,11]

\subsection{Determination of Pectinolytic and Cellulolytic Activity}

Fungal strains isolated were preliminary screened for pectinolytic and cellulolytic enzyme activity using disc plate method of Acuna-Arguelles et al (1994)[12]. The size 
of clearance zone formed around the colonies corresponds to the enzymatic activity of a particular culture. The cultures were individually plated on Czapek Dox Agar medium containing $1 \%$ pectin and carboxy-methyl cellulose (CMC) as the sole carbon source. The clearance zone formed around the colonies was determined using bromothymol blue and Congo red for pectinase and cellulase activity, respectively. The potency index of cellulase $\left(\mathrm{I}_{\mathrm{Fcel}}\right)$ and pectinase $\left(\mathrm{I}_{\mathrm{Fpect}}\right)$ activity were calculated as the ratio of zone diameter to colony diameter. The cultures showing high potency index were further analysed for enzyme quantification study.

\subsection{Pectinase and CMCase Assay}

Pectinase and cellulase activity was determined following the methods of Wang et al[13]. One $\mathrm{ml}$ of the crude enzyme supernatant was incubated with $1 \mathrm{ml}$ of $1 \%$ pectin and CMC in $0.1 \mathrm{M}$ sodium acetate buffer solution $\mathrm{pH} 5.0$ for $30 \mathrm{~min}$ at $63^{\circ} \mathrm{C}$. The resulted reducing sugars were determined according to Miller by dinitrosalisylic acid (DNSA)[14].

\subsection{Optimization of Culture Condition}

The optimization for pectinase and cellulase production was performed based on the modification of the physical parameters. According to that fungal isolates were inoculated in the synthetic medium followed by incubation at different temperatures $\left(20^{\circ} \mathrm{C}, 25^{\circ} \mathrm{C}, 30^{\circ} \mathrm{C}, 35^{\circ} \mathrm{C}, 40^{\circ} \mathrm{C}\right)$. Enzyme production was measured after 7 days of incubation by filter paper assay. Effect of $\mathrm{pH}$ on enzyme activity was determined by incubating enzyme (culture supernatant) in buffers of different $\mathrm{pH}(5.0,5.5,6.0 .6 .5,7.0)[14]$.

\section{Result}

From the result, it was observed that, the CFU/gm of the soil sample was found to be maximum in the area of Bhanjabasa $\left(4 * 10^{-4}\right)$. A total of twenty fives species fungal strains were isolated, out of which five Aspergillus strains were found to have more enzymatic activity. The strains isolated were identified as Aspergillus niger, A. terrus, A. stellatus, A. flavus, A. fumigatus.

On the basis of potency index value, two fungal isolates, Aspergillus niger and A. flavus showed the highest potential for cellulase and pectinase enzyme activity, respectively (Figure 1).

Temperature and $\mathrm{pH}$ of the growth medium plays an important role by inducing morphological changes in microbes and in enzyme secretion. The cellulase enzyme activity was maximum $\left(0.198 \mathrm{U} / \mathrm{ml}\right.$ of substrate) at temperature $30^{\circ} \mathrm{C}$ and $\mathrm{pH} 6.5$ by Aspergillus niger (Figure $2 \& 3$ ). Similar result was also reported by Sazci et al. and Jahangeer $[15,16]$. From the figure $4 \& 5$ it can be concluded that the high pectinolytic activity $(0.195 \mathrm{U} / \mathrm{ml}$ of substrate) was shown by $A$. flavus at temperature $30^{\circ} \mathrm{C}$ and $\mathrm{pH}$ 6.0. According to Marcia et al., the activities of pectinase produced by Bacillus $s p$. strains were higher than those produced by
Aspergillus niger, Aspergillus sp, A. niger ATCC20107, Aureobasidium pullulans and Tubercularia vulgaris[17]. The $\mathrm{pH}$ change observed during the growth of microbes also affects product stability in the medium[18]. At higher temperature, the organism has to spend a lot of energy for maintenance and at lower temperature transport of nutrients is hindered[19]. Hence from the result it was determined that optimum $\mathrm{pH}$ and temperature was different for each individual.

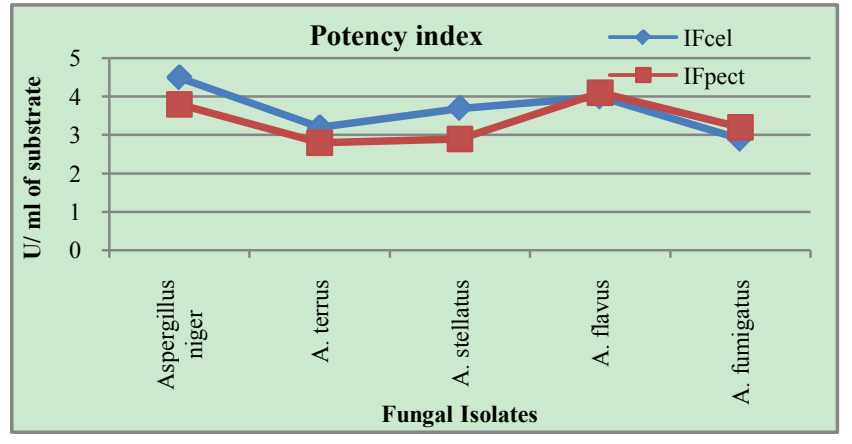

Figure 1. Potency index ( $\mathrm{I}_{\mathrm{Fcel}}$ and $\left.\mathrm{I}_{\mathrm{Fpect}}\right)$ of fungal isolates

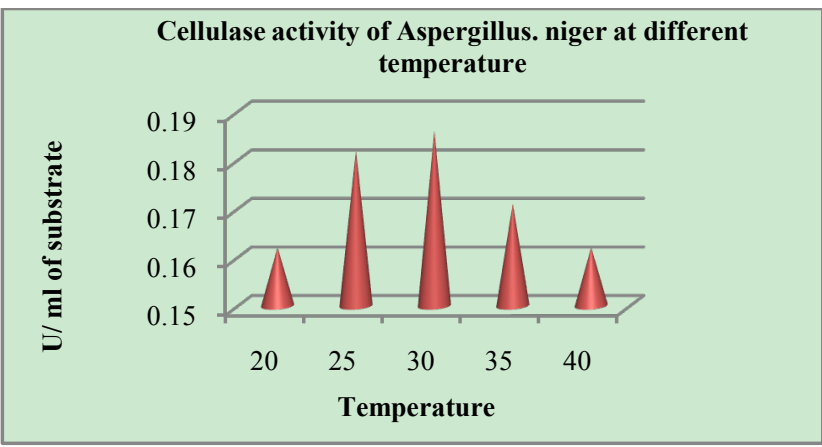

Figure 2. Cellulase activity of Aspergillus niger at different temperature

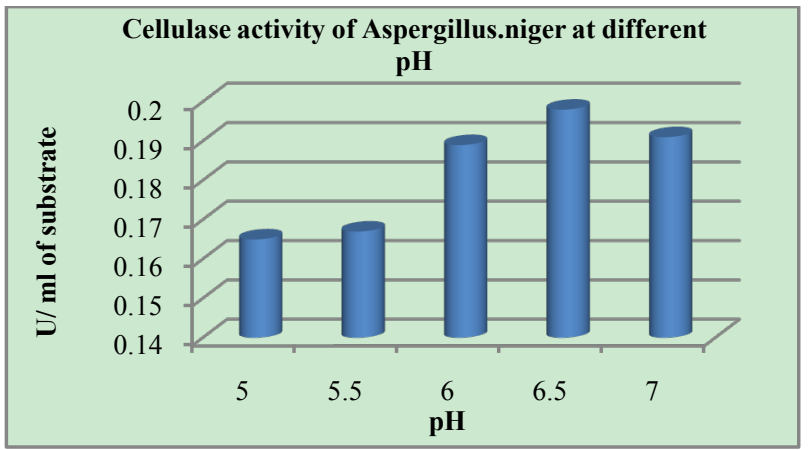

Figure 3. Cellulase activity of Aspergillus niger at different $\mathrm{pH}$

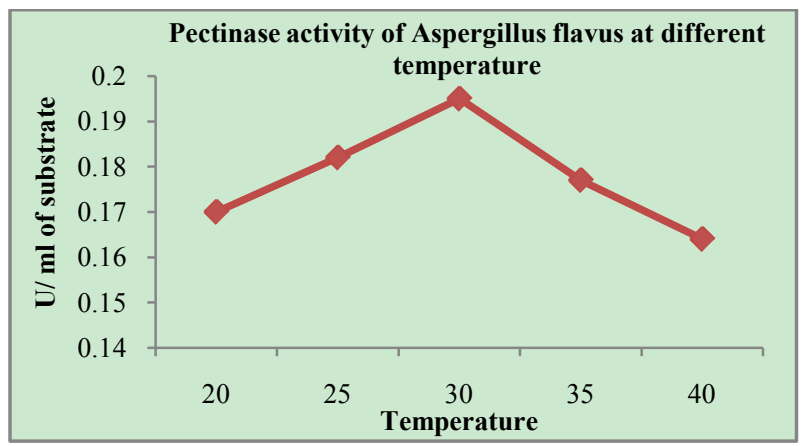

Figure 4. Cellulase activity of Aspergillus flavus at different temperature 


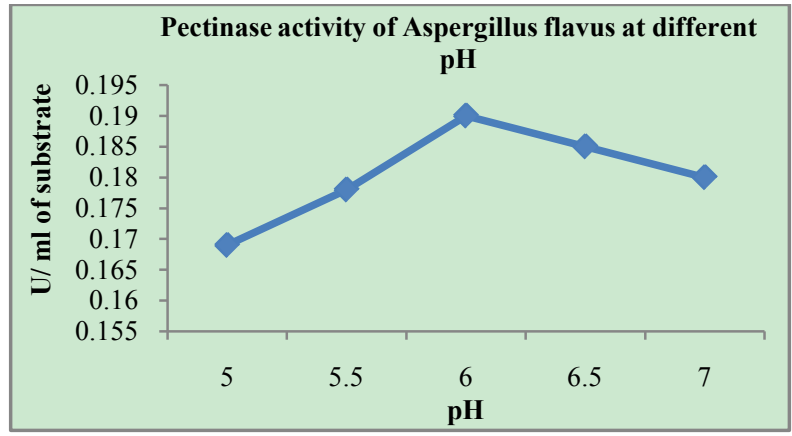

Figure 5. Cellulase activity of Aspergillus flavus at different $\mathrm{pH}$

\section{Conclusions}

In nature microorganisms produce an array of enzymes which have been exploited commercially over the years. The ability to produce pectinase and cellulase by different species of Aspergillus has become the subject of the investigation. Maximum pectinase and cellulase enzyme activity was observed by A. flavus and A. niger, respectively. Hence a further investigation should be carried out in order to maximize the enzyme activity which will open new paradigm for industry.

\section{ACKNOWLEDGEMENTS}

The authors are thankful to Prof. B.K. Mishra, Director, Institute of Minerals and Materials Technology, Bhubaneswar and Head of the Department (Botany), Utkal University, Bhubaneswar for providing necessary facilities to carry out the work.

\section{REFERENCES}

[1] A. Alaea, A. Gabilondo, F. Hernando, M. D. Moragues, J. B. Dominguez, M.J. Llama and J.L. Serra, “ Pectin Lyase production by a Penicillium italicum strain. Appl. Environm. Microbiol," 55: 1612-1616, 1989

[2] W.A.Wood and S. Kellogg (Eds): Methods in Enzymology, Vol. 161: Biomass, Part B: Lignin, Pectin, and Chitin, pp. 315-322. Academic Press, New York 1988

[3] U. Hölker, M. Höfer and J. Lenz, Biotechnological advantages of laboratory-scale solid-state fermentation with fungi. Appl. Microbiol. Biotechnol., 64: 175-186, 2004

[4] S.M. Lee and Y.M. Koo, Pilot-scale production of cellulase using T. reesei rut C-30 in fed-batch mode. J. Microbial Biotechnol. 11, 229-233, 2001
[5] Z.B. Ögel, K. Yarangümeli, H. Dürdar and I. Ifrij, Submerged cultivation of Scytalidium thermophilum on complex lignocellulosic biomass for endoglucanase production. Enzyme and Microbial. Technol., 28: 689-695, 2001

[6] K. Roopesh, R.K. Sumetra, M.S. Nampoothiri, G. Szakacs and A. Pandey, Comparison of phytase production on wheat bran and oil cakes in solid-state fermentation by Mucor racemosus. Bioresour. Technol., 97: 506-511, 2006

[7] M.G. Adsul, K.B. Bastawde, A.J. Varma and D.V. Gokhale, Strain improvement of Penicillium janthinellum NCIM 1171 for increased cellulase production. Bioresour. Technol., 98: 1467-1473, 2007

[8] J. Kaur, B.S. Chadha, B.A. Kumar and H.S. Saini, Purification and characterization of two endoglucanases from Melanocarpus sp. MTCC 3922. Bioresour. Technol., 98: 74-81, 2007

[9] V.L. Papinutti, and F. Forchiassin, Lignocellulolytic enzymes from Fomes sclerodermeus growing in solid-state fermentation. J. Food Eng., 81: 54-59, 2007

[10] O.H.K. Talbot, An Introduction to mycology. Leonard Hill, London, p. 252,1972

[11] J.W. Deacon, Introduction to modern mycology. John Wiley \& Sons Inc. New York, p. 300,1980

[12] M.E. Acuna-Arguelles, M. Gutiierrez-Rojas, G.ViniegraGonales and E.A. Favela-Torres, Production and properties of three pectinolytic activities produced by Aspergillus niger in submerged and solid-state fermentation. Appl. Microbiol. Biotechnol. 43, 808-814, 1995

[13] C. Wang, T. Hseu and C. Huang, Induction of cellulase by cello-oligosaccharides in Trichoderma konigii G-39. J. Biotechnol., 9: 47-60, 1988

[14] G.L. Miller, Use of Dinitrosalysilic acid reagent for the determination of reducing sugars. Anal. Chem., 31: 426-428, 1959

[15] A. Sazci,A.Radford and K. Erenle,Detection of cellulolytic fungi by using congo red as an indicator: a comparative study with the dinitrosalicyclic acid reagent method. J Applied Bacteriology, 61: 559-562, 1986

[16] S.Jahangeer, N. Khan, S.Jahangeer, M.Sahail, S. Shahzad, A. Ahmed and S. Ahmed Khan, Screening and characterization of fungal cellulase isolated from the native environment sources, Pak. J. Bot, 37: 739-748, 2005

[17] M.C.N. Marcia Soares, R. da Silva and E.Gomes: Screening of bacterial strains for pectinolytic activety:Characterization of thr polygalacturonase produced by Bacillus sp. Revista de Microbiologia,30:299-303,1999

[18] R. Gupta, P.Gigras, H. Mohapatra, V.K. Goswamu and B. Chauhan, Microbial a-amylases: A biotechnological perspective, Proc. Biochem., 38: 1599-1616, 2003

[19] S.J. Pirt, Principles of Cell cultivation. Blackwell Scientific, London, 1975. 